\title{
Herpes zoster ophthalmicus in a healthy child
}

\author{
Carlos G Teran, ${ }^{1}$ Marsha Medows ${ }^{2}$
}

1 Department of Infectious Diseases, Cincinnati Children's Hospital Medical Center Cincinnati, Ohio, USA 2Department of Pediatrics, New York University, New York, New York, USA

\section{Correspondence to}

Dr Carlos G Teran,

carteran79@hotmail.com
To cite: Teran $C G$

Medows M. BMJ Case Rep

Published online: [please

include Day Month Year]

doi:10.1136/bcr-2013-

009702

\section{DESCRIPTION}

A previously healthy 6-year-old male child presented in the emergency department with a 4-day history of painless erythematous-papulomacular rash that started on the left side of the forehead. The lesions became blistered and confluent, spreading to the nasal bridge and upper and lower eye lids sparing the tip of the nose (figure $1 \mathrm{~A}$ ).

Varicella vaccine was given at 1 year age and his mother denied any eruptive disease during pregnancy. PCR and Tzanck test confirmed the clinical suspicion of herpes zoster. Oral acyclovir was given for 14 days with excellent results (figure 1B). No ophthalmological complications were present during convalescence time.

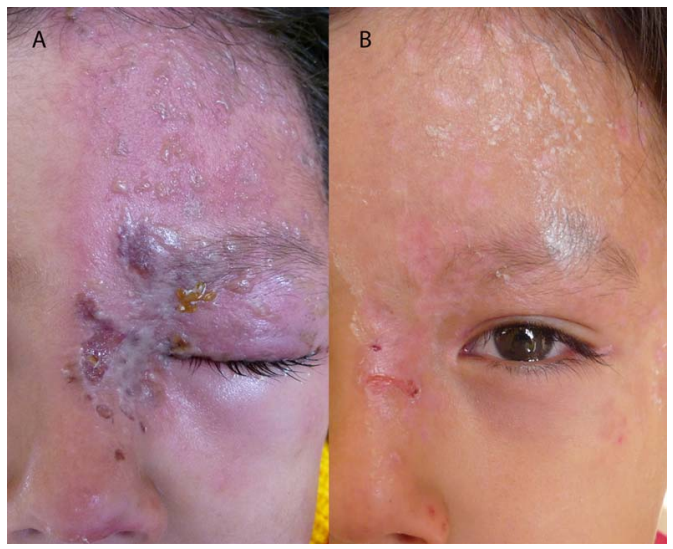

Figure 1 Herpes zoster involving the ophthalmic branch of the left trigeminal nerve $(A)$. Resolution 20 days after treatment (B).
Herpes zoster ophthalmicus in children is uncommon and is only barely described in the literature especially in immunosuppressed children. ${ }^{1}$ Nasociliary branch involvement known as Hutchinson's sign is considered a prognostic sign of sight-threatening ocular complications and is clinically manifested by the skin involvement of the tip of the nose. ${ }^{2}$

\section{Learning points}

- Varicella zoster is very rare in healthy children.

- Its presentation is less severe and usually with less sequela than in adults.

- Nasociliary branch involvement is known as Hutchinson's sign as is recognised when the tip of the nose is affected.

Contributors CGT was part of the active treatment and follow-up of the patient. He wrote the manuscript in its totality. MM was active editor of the manuscript and literature review.

Competing interests None.

Patient consent Obtained.

Provenance and peer review Not commissioned; externally peer reviewed.

\section{REFERENCES}

1 Tucker SM. Herpes zoster ophthalmicus in children. Arch Dis Child 1958;33:437-9.

2 Zaal MJ, Völker-Dieben HJ, D'Amaro J. Prognostic value of Hutchinson's sign in acute herpes zoster ophthalmicus. Graefes Arch Clin Exp Ophthalmol 2003;241:187-91.

Copyright 2013 BMJ Publishing Group. All rights reserved. For permission to reuse any of this content visit http://group.bmi.com/group/rights-licensing/permissions.

BMJ Case Report Fellows may re-use this article for personal use and teaching without any further permission.

Become a Fellow of BMJ Case Reports today and you can:

- Submit as many cases as you like

- Enjoy fast sympathetic peer review and rapid publication of accepted articles

- Access all the published articles

- Re-use any of the published material for personal use and teaching without further permission

For information on Institutional Fellowships contact consortiasales@bmjgroup.com

Visit casereports.bmj.com for more articles like this and to become a Fellow 